\title{
Travel-associated hepatitis A in Europe, 2009 to 2015
}

Julien Beauté1, Therese Westrell1, Daniela Schmid², Luise Müller³, Jevgenia Epstein ${ }^{4}$, Mia Kontio5, Elisabeth Couturier6, Mirko

Faber $^{7}$, Kassiani Mellou ${ }^{8}$, Maria-Louise Borg 9 , Ingrid Friesema ${ }^{10}$, Line Vold ${ }^{11}$, Ettore Severi ${ }^{1,12}$

1. European Centre for Disease Prevention and Control (ECDC), Stockholm, Sweden

2. Austrian Agency for Health and Food Safety, Vienna, Austria

3. Statens Serum Institut, Copenhagen, Denmark

4. Health Board, Tallinn, Estonia

5. National Institute for Health and Welfare, Helsinki, Finland

6. Santé Publique France, Saint-Maurice, France

7. Robert Koch Institut, Berlin, Germany

8. Hellenic Centre for Disease Control and Prevention, Athens, Greece

9. Infectious Disease Prevention and Control Unit, Msida, Malta

10. National Institute for Public Health and the Environment, Bilthoven, The Netherlands

11. Norwegian Institute of Public Health, Oslo, Norway

12. Karolinska Institutet, Stockholm, Sweden

Correspondence: Julien Beauté (julien.beaute@ecdc.europa.eu)

Beauté Julien, Westrell Therese, Schmid Daniela, Müller Luise, Epstein Jevgenia, Kontio Mia, Couturier Elisabeth, Faber Mirko, Mellou Kassiani, Borg MariaLouise, Friesema Ingrid, Vold Line, Severi Ettore. Travel-associated hepatitis A in Europe, 2009 to 2015. Euro Surveill. 2018;23(22):pii=1700583. https://doi. org/10.2807/1560-7917.ES.2018.23.22.1700583

Background: Travel to countries with high or intermediate hepatitis A virus (HAV) endemicity is a risk factor for infection in residents of countries with low HAV endemicity. Aim: The objective of this study was to estimate the risk for hepatitis A among European travellers using surveillance and travel denominator data. Methods: We retrieved hepatitis A surveillance data from 13 European Union (EU)/ European Economic Area (EEA) countries with comprehensive surveillance systems and travel denominator data from the Statistical Office of the European Union. A travel-associated case of hepatitis A was defined as any case reported as imported. Results: From 2009 to 2015, the 13 countries reported 18,839 confirmed cases of hepatitis A, of which $5,233(27.8 \%)$ were travel-associated. Of these, $39.8 \%$ were among children younger than 15 years. The overall risk associated with travel abroad decreased over the period at an annual rate of $3.7 \%$ ( $95 \%$ confidence interval $(\mathrm{Cl}): 0.7-2.7$ ) from 0.70 cases per million nights in 2009 to 0.51 in 2015. The highest risk was observed in travellers to Africa (2.11 cases per million nights). Cases more likely to be reported as travel-associated were male and of younger age ( 25 years). Conclusion: Travel is still a major risk factor for HAV infection in the EU/EEA, although the risk of infection may have slightly decreased in recent years. Children younger than 15 years accounted for a large proportion of cases and should be prioritised for vaccination.

\section{Background}

Hepatitis $A$ is one of the most common causes of foodborne infection worldwide [1]. The disease spreads by faecal-oral transmission either by consumption of contaminated food or person-to-person contact [2]. Although the global burden of hepatitis $A$ has decreased in the past 20 years [3], the World Health Organisation (WHO) still defines most of the world's low- and middle-income countries as experiencing high or intermediate hepatitis A virus (HAV) endemicity [4]. In Europe, the incidence of hepatitis A decreased substantially $[5,6]$ and most countries in the European Union (EU)/ European Economic Area (EEA) currently experience low or very low HAV endemicity [7]. In such populations with an increasing proportion of susceptible individuals, travel is an important risk factor for infection [2,6]. European travellers to countries with high HAV endemicity are often infected when consuming contaminated food items or drinks during travel $[8,9]$. A similar epidemiology is observed in other highincome countries such as the United States (US) where ca $40 \%$ of all hepatitis $A$ cases are travel-associated [10].

The WHO and most EU/EEA countries recommend HAV vaccination to European travellers visiting countries with intermediate or high endemicity [11]. Nevertheless, findings from a recent survey among overseas travellers from France, Germany, Italy, Spain, and the United Kingdom (UK) suggested a moderate vaccine coverage against HAV with only half of the occasional travellers visiting endemic countries vaccinated [12].

A population-based study carried out in Sweden showed that the highest risk was associated with travel to East Africa, the Middle East and the Indian subcontinent [13]. The highest risk was found among young children visiting friends and relatives, as in 


\section{FIGURE 1}

Risk of travel-associated cases of hepatitis A by million nights, 11 EU/EEA countries ${ }^{\mathrm{a}}$, 2009-2015 $(\mathrm{n}=4,705)$

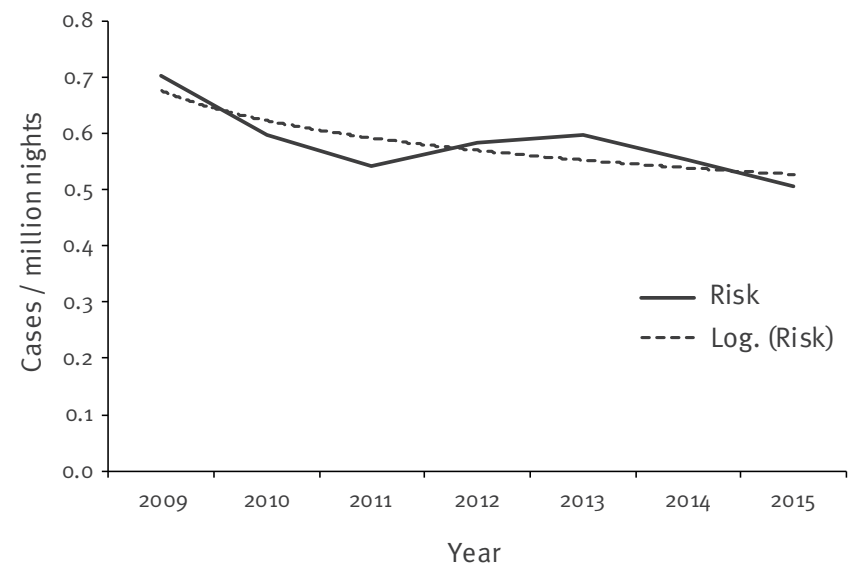

${ }^{a}$ Austria, Denmark, Estonia, Finland, France, Germany, Greece, Hungary, Luxembourg, Malta, Portugal.

another study carried out in the Netherlands [14]. It is difficult to compare findings from studies performed at national level for several reasons, including different data sources, populations and methodologies. Pooling data from several countries improves statistical power and allows for broader generalisation of the findings.

The objectives of this study were to describe the epidemiology of travel-associated hepatitis $A$, to estimate the risk for hepatitis $A$ among travellers from EU/EEA countries and to identify groups at higher risk to help target and prioritise interventions.

\section{Methods}

\section{Hepatitis A data}

Surveillance of hepatitis $A$ at the EU/EEA level is carried out by the Food- and Waterborne Diseases and Zoonoses Network (FWD-Net) under the coordination of the European Centre for Disease Prevention and Control (ECDC). The network comprises all 28 EU Member States, Iceland and Norway, which annually report hepatitis $A$ cases among their residents to the European Surveillance System (TESSy) database hosted by ECDC. Cases are reported with a set of variables including age, sex, importation status and probable country of infection.

A travel-associated case of hepatitis $A$ is defined as any case reported as imported, i.e. infected following exposure outside the reporting country during a time compatible with the incubation period. For the purpose of this analysis, we included data from $13 \mathrm{EU} /$ EEA countries (Austria, Denmark, Estonia, Finland, France, Germany, Greece, Hungary, Luxembourg, Malta, the Netherlands, Norway and Portugal) for the years 2009 to 2015. These countries (total population: 223 million) have comprehensive and compulsory

\section{FIGURE 2}

Seasonality of travel-associated cases of hepatitis A, 13 EU/EEA countries ${ }^{\mathrm{a}}$, 2009-2015 $(\mathrm{n}=5,218)$

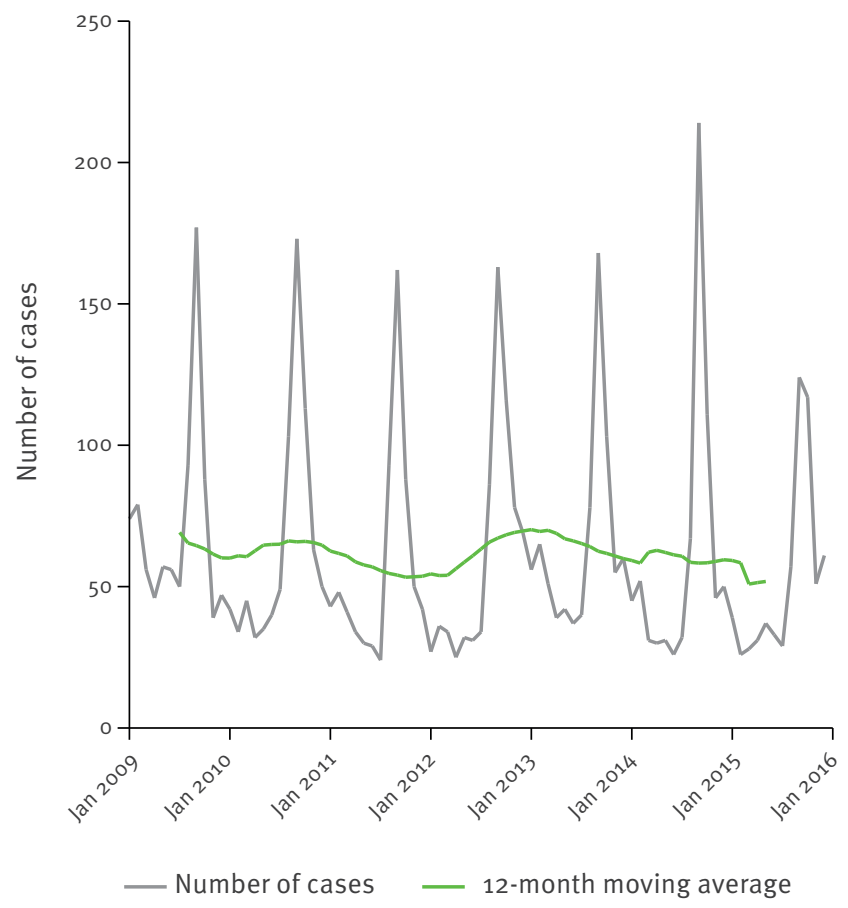

a Austria, Denmark, Estonia, Finland, France, Germany, Greece, Hungary, Luxembourg, Malta, the Netherlands, Norway, Portugal.

surveillance systems for hepatitis $A$ and reported casebased hepatitis A data for at least $80 \%$ of cases with known importation status during the study period. We chose this threshold arbitrarily to obtain reliable estimates for the proportion of travel-associated cases. In Denmark, Luxembourg and Portugal, surveillance was based on physician reporting only, whereas it was based on both laboratory and physician reporting in other countries [15]. The participating countries follow WHO recommendations as most EU/EEA countries do, i.e. they vaccinate groups at increased risk of infection. In addition, Greece has since 2008 provided universal vaccination to all children older than 12 months [7].

We included cases with known importation status who met the EU case definition criteria for a confirmed case of hepatitis $A$, i.e. any person meeting the clinical criteria and the laboratory criteria (detection of HAV nucleic acid in serum or stool or HAV-specific antibody response or detection of HAV antigen in stool) [16].

\section{Travel data}

We obtained travel denominator data for the period from 2009to 2015 from the Statistical Office of the European Union (Eurostat) [17]. We used the total number of nights spent, by destination country, which includes all nights that EU/EEA residents, aged 15 or older, spent in a collective accommodation establishment or in private tourist accommodation for personal 
Main characteristics of reported cases of hepatitis A by travel status, and adjusted predictors of travel-associated hepatitis A, 13 EU/EEA countries ${ }^{a}, 2009-2015(n=18,839)$

\begin{tabular}{|c|c|c|c|c|c|c|}
\hline \multirow[t]{2}{*}{ Characteristic } & \multicolumn{2}{|c|}{$\begin{array}{c}\text { Non-travel-associated } \\
\text { cases }\end{array}$} & \multicolumn{2}{|c|}{ Travel-associated cases } & \multirow{2}{*}{$\begin{array}{c}\text { Univariate logistic } \\
\text { regression } \\
\text { OR }(95 \% \mathrm{Cl})\end{array}$} & \multirow{2}{*}{$\begin{array}{c}\text { Multivariable logistic } \\
\text { regression }^{b} \\
\text { OR }(95 \% \mathrm{Cl})\end{array}$} \\
\hline & $\mathrm{n}$ & $\%$ & $\mathrm{n}$ & $\%$ & & \\
\hline Total & 13,606 & 100 & 5,233 & 100 & Not included & Not included \\
\hline \multicolumn{7}{|l|}{ Sex } \\
\hline Male & 7,356 & 54.1 & 2,907 & 55.6 & $1.06(0.99-1.13)$ & $1.10(1.02-1.18)$ \\
\hline Female & 6,240 & 45.9 & 2,325 & 44.4 & 1 & 1 \\
\hline Unknownc & 10 & Not included & 1 & Not included & Not included & Not included \\
\hline \multicolumn{7}{|c|}{ Age group (years) } \\
\hline$<5$ & 712 & 5.2 & 483 & 9.2 & $2.05(1.79-2.34)$ & $1.59(1.38-1.83)$ \\
\hline $5^{-14}$ & 3,230 & 23.7 & 1,600 & 30.6 & $1.50(1.37-1.63)$ & $1.38(1.25-1.52)$ \\
\hline $15-24$ & 2,206 & 16.2 & 958 & 18.3 & $1.31(1.19-1.45)$ & $1.45(1.30-1.62)$ \\
\hline $25-44$ & 3,714 & $27 \cdot 3$ & 1,230 & 23.5 & 1 & 1 \\
\hline $45-64$ & 2,481 & 18.2 & 803 & $15 \cdot 3$ & $0.98(0.88-1.08)$ & $0.80(0.72-0.89)$ \\
\hline$\geq 65$ & 1,262 & $9 \cdot 3$ & 159 & 3.0 & $0.38(0.32-0.45)$ & $0.24(0.20-0.29)$ \\
\hline Unknownc & 1 & Not included & 0 & Not included & Not included & Not included \\
\hline \multicolumn{7}{|l|}{ Outcome } \\
\hline Alive & 8,791 & 99.9 & 2,433 & 99.8 & Not included & Not included \\
\hline Dead & 8 & 0.1 & 4 & 0.2 & Not included & Not included \\
\hline Unknown ${ }^{c}$ & 4,807 & Not included & 2,796 & Not included & Not included & Not included \\
\hline
\end{tabular}

$\mathrm{Cl}$ : confidence interval; OR: odds ratio.

a Austria, Denmark, Estonia, Finland, France, Germany, Greece, Hungary, Luxembourg, Malta, the Netherlands, Norway, Portugal.

${ }^{b}$ Adjusted for year and reporting country with France as reference.

c Percentages exclude the unknown.

or professional purposes. In most countries, this information is collected through household surveys. The collection of data should conform to the specifications described in the Methodological manual for tourism statistics [18]. A country may apply weighting procedures according to the sampling design used. Since travel nights were not available for all combinations of the different countries of residence with the different destination countries for all years, we estimated the total number of nights from the mean number of nights for the available years multiplied by 7 (study period of 7 years).

\section{Analysis}

We compared travel-associated cases of hepatitis A with non-travel-associated cases for main characteristics. We defined the risk for travel-associated hepatitis $A$ as the rate of travel-associated cases per million nights spent in a given destination (region or continent) by all travellers from the reporting country. We excluded France from the analysis by destination because information on the probable country of infection was not available. We also excluded Estonia and Norway for this part of the analysis because travel data were missing for some destinations. We considered five main regions as destinations (Africa, America, Asia, Europe and Oceania). Following Eurostat grouping, we divided America further into (i) North America and (ii) Central and South America (including Mexico). In Europe, we distinguished EU countries from other European countries (including Turkey). We calculated 95\% confidence intervals $(\mathrm{Cl})$ for risk, assuming a Poisson distribution. To assess the trend in the annual risk for travel-associated hepatitis A over time, we estimated the annual rate of change and its $95 \% \mathrm{Cl}$ using a log-linear regression of risk for travel-associated hepatitis $A$ associated with overseas travel in the period from 2009 to 2015 .

We compared continuous variables across strata by Mann-Whitney U test. We compared categorical variables using the chi-squared or Fisher's exact tests with a significance level of less than 0.05 .

To further characterise travel-associated hepatitis A, we assessed the association of age and sex with the cases' travel status (dependent variable) in a logistic regression analysis and estimated adjusted odds ratios (OR) and $95 \% \mathrm{Cl}$.

\section{Ethics statement}

Hepatitis $A$ is part of the 52 communicable diseases for which ECDC routinely collects, analyses and disseminates surveillance data as stated by the Article 3 of its founding regulation. TESSy data are pseudonymised 
Number of nights spent on overseas trips, by reporting country and world region of destination, 13 EU/EEA countries ${ }^{\text {, }}$ 2009-2015 ( $\mathrm{n}=9,638$ million)

\begin{tabular}{|c|c|c|c|c|c|c|}
\hline \multirow{3}{*}{ Country } & \multicolumn{6}{|c|}{ Nights spent on oversea trips } \\
\hline & \multirow{2}{*}{ n (million) } & \multicolumn{5}{|c|}{ Distribution by destination (\%) } \\
\hline & & Africa & America & Asia & Europe & Oceania \\
\hline Austria & 469 & 3.8 & 6.6 & 6.8 & 81.9 & 0.9 \\
\hline Denmark & 364 & 3.6 & 8.9 & 9.6 & 76.8 & 1.1 \\
\hline Estonia & 52 & 3.1 & 18.5 & 7.1 & 71.3 & No data \\
\hline Finland & 313 & 2.6 & 7.6 & 11.3 & 77.0 & 1.5 \\
\hline France & 1,500 & 13.3 & 12.8 & 8.9 & 63.6 & 1.4 \\
\hline Germany & 4,971 & 5.1 & 8.6 & 7.3 & 77.9 & 1.2 \\
\hline Greece & 59 & 3.0 & 6.3 & 5.5 & 85.0 & 0.2 \\
\hline Hungary & 187 & 2.1 & 9.8 & 4.6 & 82.4 & 1.1 \\
\hline Luxembourg & 73 & 4.5 & 6.1 & 4.2 & 84.9 & 0.3 \\
\hline Malta & 16 & 5.8 & 4.3 & 4.9 & 82.2 & 2.8 \\
\hline The Netherlands ${ }^{b}$ & 1,180 & 3.9 & 8.3 & 6.5 & 80.3 & 1.1 \\
\hline Norway $^{c}$ & 369 & 4.2 & 8.2 & 9.6 & 77.0 & 1.0 \\
\hline Portugal & 85 & 9.6 & 12.4 & 3.6 & 73.8 & 0.7 \\
\hline Total & 9,638 & 4.6 & 8.5 & 7.4 & 78.4 & 1.1 \\
\hline
\end{tabular}

a Austria, Denmark, Estonia, Finland, France, Germany, Greece, Hungary, Luxembourg, Malta, the Netherlands, Norway, Portugal.

${ }^{b}$ Number of nights only available for 2012-2015. The figure used is an estimate based on the average for available years.

c Number of nights only available for 2009-2011. The figure used is an estimate based on the average for available years.

and processed for public interest in the area of public health. Informed consent was not required.

\section{Results}

In the period from 2009 to 2015 , the 13 participating countries reported 20,556 confirmed cases of hepatitis A, of which 18,839 (91.6\%) had known travel status. Of these $18,839,5,233(27.8 \%)$ were travelassociated (Table 1). Four countries had proportions of travel-associated cases below $25 \%$ : Hungary (1.1\%), Greece (11.3\%), Estonia (17.0\%) and Malta (22.7\%). Of the 5,233 travel-associated cases, 2,581 (49.3\%) were reported with available information on the probable country of infection. When excluding France, information on probable country of infection was available for $2,581(94.8 \%)$ of 2,723 travel-associated cases.

\section{Demographics}

Of the 5,232 travel-associated cases with known sex, 2,907 (55.6\%) were male giving a male-to-female ratio of 1.3:1 (Table 1). There was a non-significant difference between the proportion of travel-associated cases in male compared with female cases $(28.3 \%$ vs $27.2 \% ; p=0.07)$. The male-to-female ratio was lower in younger and older age groups (1.1:1 below 15 years and 1.0:1 at 65 years and above), peaking at 1.5:1 for those 25-44 years of age. Of the 5,233 travel-associated cases, 2,083 (39.8\%) were children younger than 15 years. The proportion of travel-associated cases in that age group was below $30 \%$ in Malta (17.0\%), Hungary (17.0\%) and Estonia (4.4\%). Of the 2,437 travel-associated case with known outcome, four died (0.2\%).

\section{Trend and seasonality}

Over the study period, the average annual number of travel-associated cases was 748 (range: 637-867). The highest numbers of travel-associated cases were observed in 2009 and 2013 with 867 and 795 cases, respectively. Annual numbers of nights spent abroad were available for all countries and all years except for the Netherlands (only years 2012-15) and Norway (only years 2009-11). Between 2009 and 2015, for the 11 countries with available data on nights spent for all years, the overall annual risk for hepatitis $A$ associated with overseas travel was 0.58 cases per million nights. The logarithmic trendline showed a decrease at an annual rate of $3.7 \%(95 \% \mathrm{Cl}: 0.7-2.7)$ from 0.70 cases per million nights in 2009 to 0.51 in 2015 (Figure 1).

Of the 5,218 travel-associated cases with known month of reporting, 2,016 (38.6\%) were reported between August and October, including 1,181 (22.6\%) in the month of September alone (Figure 2). Of the 2,078 travel-associated cases younger than 15 years for whom the month of reporting was known, 1,235 (59.4\%) were reported between August and October.

\section{Travel patterns}

From 2009 to 2015 , residents from the 13 participating countries spent ca 9.6 billion nights abroad (Table 2). The most visited regions were Europe $(78.4 \%$ of all nights spent, including Turkey), America (8.5\%) and Asia (7.4\%). Travellers only spent $4.6 \%$ of their nights in Africa and $1.1 \%$ in Oceania. Travellers from France and Portugal spent a larger proportion (13.3\% 
TABLE 3

Number of travel-associated cases of hepatitis A, number of nights spent and risk by reporting country, 13 EU/EEA countries, 2009-2015 $(n=5,233)$

\begin{tabular}{|c|c|c|c|c|c|}
\hline \multirow{2}{*}{ Country } & \multicolumn{3}{|c|}{ Travel-associated cases } & \multirow{2}{*}{$\begin{array}{l}\text { Nights } \\
\text { (million) }\end{array}$} & \multirow{2}{*}{ Cases/million nights $(95 \% \mathrm{Cl})$} \\
\hline & $\mathrm{n}$ & $\%$ & $\%<15$ years & & \\
\hline Austria & 96 & 1.8 & 36.5 & 469 & $0.21(0.17-0.25)$ \\
\hline Denmark & 167 & 3.2 & 41.9 & 364 & $0.46(0.39-0.53)$ \\
\hline Estonia & 45 & 0.9 & 4.4 & 52 & $0.87(0.64-1.16)$ \\
\hline Finland & 78 & 1.5 & 38.5 & 313 & $0.25(0.20-0.31)$ \\
\hline France & 2,510 & 48.0 & 43.1 & 1,500 & $1.67(1.61-1.74)$ \\
\hline Germany & 1,619 & 30.9 & 37.1 & 4,971 & $0.33(0.31-0.34)$ \\
\hline Greece & 61 & 1.2 & 34.4 & 59 & $1.03(0.79-1.33)$ \\
\hline Hungary & 47 & 0.9 & 17.0 & 187 & $0.25(0.19-0.33)$ \\
\hline Luxembourg & 15 & 0.3 & 33.3 & 73 & $0.20(0.11-0.34)$ \\
\hline Malta & 5 & 0.1 & 20.0 & 16 & $0.32(0.10-0.74)$ \\
\hline The Netherlands ${ }^{a}$ & 400 & 7.6 & 40.8 & 1,180 & $0.34(0.31-0.37)$ \\
\hline Norway ${ }^{b}$ & 128 & 2.4 & 34.4 & 369 & $0.35(0.29-0.41)$ \\
\hline Portugal & 62 & 1.2 & 33.9 & 85 & $0.73(0.56-0.94)$ \\
\hline Total & 5,233 & 100 & 39.8 & 9,638 & $0.54(0.53-0.56)$ \\
\hline
\end{tabular}

$\mathrm{Cl}$ : confidence interval.

a Number of nights only available for 2012-2015. The figure used is an estimate based on the average for available years.

${ }^{b}$ Number of nights only available for 2009-2011. The figure used is an estimate based on the average for available years.

and $9.6 \%$, respectively) of their nights in Africa compared with those from other countries. Travellers from Denmark, Finland and Norway spent $9.6 \%$ or more of their nights in Asia.

Within Europe, most nights were spent in the EU (84.5\%). This proportion was below $80 \%$ for travellers from Estonia (71.5\%) and Greece (58.4\%). Overall, $63.8 \%$ of the nights spent in America were in North America.

Nine of the 13 countries included had a risk between 0.20 and 0.46 cases per million nights. Travellers from France (1.67 cases per million nights), Greece (1.03), Estonia (0.87) and Portugal (0.73) had a higher risk (Table 3).

Of the 2,581 cases reported by 12 countries with information on probable country of infection (data from France excluded), 2,416 (93.6\%) resided in the 10 countries for which travel data were available for all destinations (travel data for Estonia and Norway were not available for all destinations). Among these 2,416 cases, the overall risk for travel-associated hepatitis $A$ was 0.31 cases per million nights spent overseas. The highest risks were observed with travel to Africa (2.11 cases per million nights) and Asia (1.25) (Table 4).

Travel to Egypt, Turkey and Morocco accounted for $30.9 \%$ of all travel-associated cases reported with information on probable country of infection (Table 5). While most cases returning from Turkey and Morocco were reported in the period from August to October (64.2\% and $62.6 \%$, respectively), $47.7 \%$ of cases returning from Egypt were reported between November and February. Of note, of the 69 cases associated with travel to Italy, 24 were reported in 2013 . The proportion of cases younger than 15 years was above $70 \%$ for cases reported with a travel to Afghanistan, Ethiopia, Iraq or Pakistan and below 10\% for cases who travelled to France, Greece, Spain and Thailand. The proportion of cases younger than 15 years was noticeably low in travellers to Egypt (14.7\%) and India (17.9\%) compared with neighbouring countries such as Lebanon (45.0\%) or Pakistan (73.6\%). In the EU, this proportion was higher in travellers to Romania (29.4\%), Bulgaria (22.6\%) and Italy (20.3\%) compared with other EU countries.

\section{Multivariable analysis}

Male travellers were more likely than female travellers to have acquired their infection abroad (adjusted $\mathrm{OR}=1.10 ; 95 \% \mathrm{Cl}: 1.02-1.18$ ) (Table 1 ), and younger cases were more likely to be travel-associated than older cases. Compared with those aged 25-44 years, children younger than 5 years were $60 \%$ more likely to be reported with a probable infection abroad (adjusted $\mathrm{OR}=1.59 ; 95 \% \mathrm{Cl}: 1.38-1.83)$.

\section{Discussion}

\section{Principal findings}

In the participating European countries, $27.8 \%$ of reported hepatitis $A$ cases were travel-associated. Both 
TABLE 4

Number of travel-associated cases of hepatitis A, number of nights spent and risk by travel destination, 10 EU/EEA countries $^{\mathrm{a}}, 2009-2015(\mathrm{n}=2,416)$

\begin{tabular}{|c|c|c|c|c|c|c|}
\hline \multirow{3}{*}{$\begin{array}{l}\text { Region } \\
\text { Total (all regions) }\end{array}$} & \multicolumn{3}{|c|}{ Travel-associated cases } & \multirow{2}{*}{\multicolumn{2}{|c|}{$\begin{array}{c}\text { Nights } \\
\text { (million, estimate } 2009-15^{\mathrm{b}} \text { ) }\end{array}$}} & \multirow{3}{*}{$\begin{array}{l}\text { Cases/million nights }(95 \% \mathrm{Cl}) \\
\text { 0.31 (0.30-0.32) }\end{array}$} \\
\hline & \multirow{2}{*}{$\begin{array}{c}n \\
2,416 \\
\end{array}$} & \multirow{2}{*}{$\begin{array}{c}\% \\
100 \\
\end{array}$} & \multirow{2}{*}{$\begin{array}{c}\%<15 \text { years } \\
\mathbf{3 9 . 8} \\
\end{array}$} & & & \\
\hline & & & & 7,794 & 100 & \\
\hline Africa & 753 & 31.2 & 33.3 & 357 & 4.6 & $2.11(1.96-2.27)$ \\
\hline \multicolumn{7}{|l|}{ America } \\
\hline North America & 10 & 0.4 & 0.0 & 412 & 5.3 & $0.02(0.01-0.04)$ \\
\hline Central and South America ${ }^{c}$ & 106 & $4 \cdot 4$ & 14.2 & 228 & 2.9 & $0.46(0.38-0.56)$ \\
\hline Asia & 705 & 29.2 & 50.4 & 564 & 7.2 & $1.25(1.16-1.35)$ \\
\hline \multicolumn{7}{|l|}{ Europe } \\
\hline EU 28 & 427 & 17.7 & 13.6 & 5,150 & 66.1 & $0.08(0.07-0.09)$ \\
\hline Other European countries ${ }^{d}$ & 410 & 17.0 & 56.8 & 995 & 12.8 & $0.41(0.37-0.45)$ \\
\hline Oceania & 5 & 0.2 & 0.0 & 88 & 1.1 & $0.06(0.02-0.13)$ \\
\hline
\end{tabular}

$\mathrm{Cl}$ : confidence interval.

a Austria, Denmark, Finland, Germany, Greece, Hungary, Luxembourg, Malta, the Netherlands and Portugal.

b The number of travel-associated cases was aggregated for the period 2009 to 2015, but travel nights were not available for all combinations of the different countries of residence with the different destination countries for all years. We therefore estimated the total number of nights from the mean number of nights for the available years multiplied by 7 (study period of 7 years).

c Including Mexico.

d Including Turkey.

this proportion and the number of travel-associated cases were stable over the study period. However, the risk for travel-associated hepatitis $A$ per nights spent overseas decreased. This is consistent with decreases reported from the Netherlands [14] and Denmark in the 2000 [19]. The large number of cases reported in 2013 may have been related to a large multistate food-borne outbreak with more than 1,500 cases in the EU/EEA [20]. It is possible that other outbreaks also played a role in the fluctuations observed in these data. More than $60 \%$ of all travel-associated hepatitis A cases were associated with travel to Africa and Asia, although these destinations accounted for less than $15 \%$ of all nights spent overseas. These findings are hardly surprising because these two continents host most countries with high endemicity [4]. However, these estimates at continental level may mask important disparities. Some European countries are also at moderate to high risk for HAV infection.

Age and seasonality appeared to be related to specific destinations. Pakistan was associated with a large proportion of cases younger than 15 years, most of whom were reported between August and October. These children were most probably accompanying their parents during the summer vacation. Conversely, Egypt, India and most European countries were associated with more cases among adults and a less pronounced seasonality. This may be suggestive of leisure travel without children or business travel which is year-round for some destinations.

Interestingly, most countries of residency included in the analysis had comparable travel patterns and estimated risks, suggesting that some of these findings could be generalised to other European countries not included in this study. The higher risk observed in travellers from France and Portugal, compared with other countries, could be partly driven by a higher proportion of nights spent in Africa, a destination where travellers are at high risk of acquiring hepatitis A. Similarly, travellers from Estonia and Greece had a high proportion of nights spent in Eastern Europe and Turkey, which are destinations of higher risk compared with Western Europe [4].

\section{Strengths and weaknesses of the study}

This study included more than 5,000 travel-associated hepatitis A cases reported by 13 countries. These countries account for more than $40 \%$ of the EU/EEA population. Our findings provide a good picture of the epidemiology of travel-associated hepatitis A in Europe in recent years. However, this study had some limitations. Firstly, a large proportion of mild non-specific or entirely asymptomatic hepatitis A cases, especially among children, were probably not captured by the surveillance systems. In addition, given the long incubation period of hepatitis $A$ and the possibility of a case having visited several countries, countries may have misclassified some of their cases, and it is challenging to assess the effect of this type of error in our analysis. Secondly, information on the probable country of infection was not available for cases reported by France, which accounted for nearly half of travel-associated cases reported over the study period. Thirdly, we excluded countries with low coverage of their surveillance system (e.g. Italy) or low completeness of the travel status (e.g. the UK). Fourthly, nights 
TABLE 5

Top destinations for travel-associated hepatitis A cases, 12 EU/EEA countries ${ }^{a}, 2009-2015(n=2,581)$

\begin{tabular}{|c|c|c|c|c|c|}
\hline \multirow{2}{*}{ Rank } & \multirow{2}{*}{ Destination country } & \multirow{2}{*}{ Region } & \multicolumn{3}{|c|}{ Travel-associated cases } \\
\hline & & & $\mathrm{n}$ & $\%$ & $\%<15$ years \\
\hline 1 & Turkey & Other European countries & 318 & 12.3 & 61.3 \\
\hline 2 & Egypt & Africa & 279 & 10.8 & 14.7 \\
\hline 3 & Morocco & Africa & 200 & 7.7 & 52.0 \\
\hline 4 & Pakistan & Asia & 140 & 5.4 & 73.6 \\
\hline 5 & Afghanistan & Asia & 130 & 5.0 & 80.0 \\
\hline 6 & India & Asia & 106 & 4.1 & 17.9 \\
\hline 7 & Syria & Asia & 92 & 3.6 & 52.2 \\
\hline 8 & Spain & EU 28 & 86 & 3.3 & 3.5 \\
\hline 9 & Italy & EU 28 & 69 & 2.7 & 20.3 \\
\hline 10 & Lebanon & Asia & 60 & 2.3 & 45.0 \\
\hline 11 & Namibia & Africa & 59 & 2.3 & 15.3 \\
\hline 12 & Romania & EU 28 & 51 & 2.0 & 29.4 \\
\hline 13 & Iraq & Asia & 42 & 1.6 & 73.8 \\
\hline 14 & Bulgaria & EU 28 & 31 & 1.2 & 22.6 \\
\hline 14 & France & EU 28 & 31 & 1.2 & 6.5 \\
\hline 16 & Ethiopia & Africa & 29 & 1.1 & $79 \cdot 3$ \\
\hline 17 & Peru & Central and South America & 28 & 1.1 & 25.0 \\
\hline 18 & Croatia & Africa & 26 & 1.0 & 26.9 \\
\hline 19 & Philippines & Asia & 25 & 1.0 & 24.0 \\
\hline 20 & Greece & EU 28 & 24 & 0.9 & 8.3 \\
\hline 20 & Thailand & Asia & 24 & 0.9 & 8.3 \\
\hline \multicolumn{3}{|c|}{ Other destinations } & 731 & 28.3 & 25.2 \\
\hline \multicolumn{3}{|l|}{ Total } & 2,581 & 100 & 36.9 \\
\hline
\end{tabular}

${ }^{a}$ Austria, Denmark, Estonia, Finland, Germany, Greece, Hungary, Luxembourg, Malta, the Netherlands, Norway and Portugal.

spent by EU/EEA residents younger than 15 years were not available. Although children are unlikely to travel without their parents, we may have overestimated the risk in destinations with a large proportion of cases in children (e.g. Asia). Unfortunately, travel denominator data at country level were not available for most destination countries outside Europe. Lastly, there were limitations related to the travel data. These data were collected mostly via household survey [17] which is prone to recall bias. In addition, number of nights spent in destinations with few travellers (e.g. Oceania) can show high variations over time [17]. However, we think that overall, these data were reliable with little variation over the study period for most destinations considered in the analysis.

Information on travel purpose and probable route of infection were not available. Some authors have recommended recording the travel purpose in order to inform public health strategies [21]. For example, people visiting friends and relatives are at a higher risk of acquiring travel-associated infection [22-24]. However, visiting friends and relatives may not be the sole purpose of the journey and the classical definition of visiting friends and relatives has been challenged [25]. Information on the probable route of infection may also be useful for informing prevention strategies as hepatitis A infection can also be sexually transmitted and men who have sex with men are a known risk group [26].

\section{Comparison with other studies}

Our risk estimate ( 0.54 cases per million nights) is higher than data reported by Askling et al. who estimated a risk of travel-associated hepatitis $A$ of 0.61 cases per 100,000 travel months (i.e. 0.20 cases per million nights) among Swedish travellers [13]. Our overall estimate was probably driven by France, a country whose travellers spent more nights in Africa and were shown to be less likely to be vaccinated compared with other European travellers [12]. As in our study, Askling at al. found a higher risk associated with travel to some parts of Africa and Asia. The proportion of travelassociated cases in our study (ca 30\%) was lower than in the US (ca 40\%) [10]. However, this overall proportion masks important disparities across countries and was heavily influenced by countries reporting many locally acquired cases such as Hungary. Alongside Romania and Slovakia, Hungary was one of the few EU/EEA countries with a notification rate above 10 cases per 100,000 population in 2014 [15]. In the late $1990 s$, routine hepatitis A vaccination of children was 
implemented in those states in the US with the highest incidence, leading to decreases in incidence among younger age groups [27]. It is possible that this strategy, implemented at local level, had a large impact on domestically acquired cases overall by decreasing HAV circulation in the US.

The high proportion of infection in children returning from countries less frequented by tourists (e.g. Afghanistan, Iraq or Pakistan) is very suggestive of travel to visit friends and relatives or recent immigration. This would confirm reports from Australia where travel-associated infections in children were more frequently associated with visiting friends and relatives than in adults [22]. The large number of refugees entering Europe in 2015 is unlikely to have had any major effect on our findings because reports from Germany and Greece suggested that hepatitis A cases in this population were only observed in late 2015 and 2016 $[28,29]$.

\section{Possible explanations and implications for} clinicians and policymakers

During the period from 2009to 2015, the notification rate of hepatitis $A$ cases in the EU/EEA was fairly stable at ca three cases per 100,000 population, with the highest notification rate observed in children aged 5-14 years. Our data suggest that the risk of travel-associated cases decreased slightly over the period. A molecular cluster analysis carried out in the Netherlands showed that travelling children were an important group for introduction and further transmission of HAV [30]. HAV vaccination, for children of families travelling to countries of high or intermediate endemicity would probably have a high impact on the number of travel-associated hepatitis A cases in Europe and consequently on secondary locally acquired cases. For example, HAV incidence in children of Moroccan or Turkish descent steadily declined after the introduction of targeted HAV vaccination programmes in the Netherlands [31]. More generally, hepatitis A vaccine is recommended for all non-immune travellers to countries of intermediate or high endemicity. Since a single dose of hepatitis A vaccine provides high protection even when given shortly before departure [32], any increase in opportunities for vaccination would be beneficial (e.g. vaccination clinics at airports). However, the recent vaccine shortages in some European countries may jeopardise efforts to promote vaccination [33]. Studies exploring other factors for not getting vaccinated (risk perception, cost etc.) would also help design effective public health measures [34].

\section{Conclusion}

Travel remains a major risk factor for HAV infection in the EU/EEA, although the risk of infection may have slightly decreased over recent years. This still represents a considerable cause of morbidity which could be avoided since a safe, effective and affordable vaccine is available. Children younger than 15 years account for a large proportion of cases and should be prioritised for vaccination, particularly when travelling to visit relatives and friends in HAV-endemic countries.

\section{Acknowledgements}

We are very grateful to our colleagues in the FWD-Net who provided the data. We particularly would like to acknowledge Sophie Quoilin (Belgium), Sanja Kurečić Filipović and Iva Pem Novosel (Croatia), Jitka Castkova and Vratislav Nemecek (Czech Republic), Sofie Gillesberg Raiser (Denmark), Irina Filippova (Estonia), Ruska Rimhanen-Finne (Finland), AnneMarie Roque-Afonso (France), Kassiani Gkolfinopoulou (Greece), Niamh Murphy (Ireland), Stefania D’Amato and Anna Rita Ciccaglione (Italy), Tanya Melillo (Malta), Bernardo Guzmán Herrador (Norway), Piotr Polanski and Anna Baumann-Popczyk (Poland), Maria Avdicova and Jan Mikas (Slovak Republic), Elena Vanessa Martínez and Carmen Varela (Spain).

\section{Conflict of interest}

None declared.

\section{Authors' contributions}

JB conceived the study and ran the analysis. All authors interpreted the results. JB, ES, and TW prepared the manuscript. All authors contributed to revising the manuscript, providing substantial intellectual input.

\section{References}

1. Havelaar AH, Kirk MD, Torgerson PR, Gibb HJ, Hald T, Lake RJ, et al. World Health Organization global estimates and regional comparisons of the burden of foodborne disease in 2010. PLoS Med. 2015;12(12):e1001923. https://doi.org/10.1371/journal. pmed.1001923 PMID: 26633896

2. Koff RS. Hepatitis A. Lancet. 1998;351(9116):1643-9. https:// doi.org/10.1016/S0140-6736(98)01304-X PMID: 9620732

3. Stanaway JD, Flaxman AD, Naghavi M, Fitzmaurice C, Vos T, Abubakar I, et al. The global burden of viral hepatitis from 1990 to 2013: findings from the Global Burden of Disease Study 2013. Lancet. 2016;388(10049):1081-8. https://doi. org/10.1016/S0140-6736(16)30579-7 PMID: 27394647

4. Jacobsen KH, Wiersma ST. Hepatitis A virus seroprevalence by age and world region, 1990 and 2005 . Vaccine. 2010;28(41):6653-7. https://doi.org/10.1016/j. vaccine.2010.08.037 PMID: 20723630

5. Blachier M, Leleu H, Peck-Radosavljevic M, Valla DC, RoudotThoraval $F$. The burden of liver disease in Europe: a review of available epidemiological data. J Hepatol. 2013;58(3):593-608. https://doi.org/10.1016/j.jhep.2012.12.005 PMID: 23419824

6. Gossner CM, Severi E, Danielsson N, Hutin Y, Coulombier D. Changing hepatitis A epidemiology in the European Union: new challenges and opportunities. Euro Surveill. 2015;20(16):21101. https://doi.org/10.2807/1560-7917.ES2015.20.16.21101 PMID: 25953274

7. European Centre for Disease Prevention and Control (ECDC). Hepatitis A virus in the EU/EEA, 1975-2014. A systematic review of seroprevalence and incidence comprising European surveillance data and national vaccination recommendations. Stockholm: ECDC; 2016. Available from: https://ecdc.europa. eu/en/publications-data/hepatitis-virus-eueea-1975-2014

8. Kumbang J, Ejide S, Tedder RS, Ngui SL. Outbreak of hepatitis $A$ in an extended family after importation by non-immune travellers. Epidemiol Infect. 2012;140(10):1813-20. https://doi. org/10.1017/So950268811002561 PMID: 22142642

9. Sane J, MacDonald E, Vold L, Gossner C, Severi E, on behalf of the International Outbreak Investigation Team. Multistate foodborne hepatitis A outbreak among European tourists returning from Egypt--need for reinforced vaccination recommendations, November 2012 to April 2013. Euro Surveill. 2015;20(4):21018. https://doi.org/10.2807/1560-7917. ES2015.20.4.21018 PMID: 25655054 
10. Klevens RM, Miller JT, Iqbal K, Thomas A, Rizzo EM, Hanson $\mathrm{H}$, et al. The evolving epidemiology of hepatitis a in the United States: incidence and molecular epidemiology from population-based surveillance, 2005-2007. Arch Intern Med. 2010;170(20):1811-8. https://doi.org/10.1001/ archinternmed.2010.401 PMID: 21059974

11. WHO position paper on hepatitis A vaccines - June 2012. Wkly Epidemiol Rec. 2012;87(28/29):261-76. PMID: 22905367

12. Pedersini R, Marano C, De Moerlooze L, Chen L, Vietri J. HAV \& HBV vaccination among travellers participating in the National Health and Wellness Survey in five European countries. Travel Med Infect Dis. 2016;14(3):221-32. https://doi.org/10.1016/j. tmaid.2016.03.008 PMID: 27000975

13. Askling HH, Rombo L, Andersson Y, Martin S, Ekdahl K. Hepatitis A risk in travelers. J Travel Med. 2009;16(4):2338. https://doi.org/10.1111/j.1708-8305.2009.00307.x PMID: 19674261

14. Sane J, de Sousa R, van Pelt W, Petrignani M, Verhoef L, Koopmans M. Risk of hepatitis A decreased among Dutch travelers to endemic regions in 2003 to 2011. J Travel Med. 2015;22(3):208-11. https://doi.org/10.1111/jtm.12181 PMID: 25530483

15. European Centre for Disease Prevention and Control (ECDC). Hepatitis A. Annual epidemiological report 2014. Stockholm: ECDC; 2016. Available from: https://www.ecdc.europa.eu/en/publications-data/ hepatitis-annual-epidemiological-report-2016-2014-data

16. European Commission. Commission Implementing Decision 2012/506/EU of 8 August 2012 amending Decision 2002/253/ EC laying down case definitions for reporting communicable diseases to the Community network under Decision No 2119/98/EC of the European Parliament and of the Council. Official Journal of the European Union. Luxembourg: Publications Office of the European Union; 27.9.2012:L262. Available from: http://eur-lex.europa.eu/LexUriServ/ LexUriServ.do?uri=0J:L:2012:262:0001:0057:EN:PDF

17. Annual data on trips of EU residents. Luxembourg: Eurostat. [Accessed: 15 Nov 2017. Available from: http://ec.europa.eu/ eurostat/cache/metadata/de/tour_dem_esms.htm

18. Methodological manual for tourism statistics. Version 3.1. 2014 edition. Luxembourg: Eurostat; 2015. Available from: http://ec.europa.eu/eurostat/web/ products-manuals-and-guidelines/-/KS-GQ-14-013

19. Nielsen US, Larsen CS, Howitz M, Petersen E. Hepatitis A among Danish travellers 1980-2007. J Infect. 2009;58(1):47-52. https://doi.org/10.1016/j.jinf.2008.10.010 PMID: 19059649

20. Severi E, Verhoef L, Thornton L, Guzman-Herrador BR, Faber M, Sundqvist $L$, et al. Large and prolonged food-borne multistate hepatitis $A$ outbreak in Europe associated with consumption of frozen berries, 2013 to 2014. Euro Surveill. 2015;20(29):21192. https://doi.org/10.2807/1560-7917.ES2015.20.29.21192 PMID: 26227370

21. Neave PE, Heywood AE, Gibney KB, Leder K. Imported infections: What information should be collected by surveillance systems to inform public health policy? Travel Med Infect Dis. 2016;14(4):350-9. https://doi.org/10.1016/j. tmaid.2016.05.007 PMID: 27235839

22. Heywood AE, Zwar N, Forssman BL, Seale H, Stephens N, Musto J, et al. The contribution of travellers visiting friends and relatives to notified infectious diseases in Australia: statebased enhanced surveillance. Epidemiol Infect. 2016;1-10. PMID: 27574034

23. Warne B, Weld LH, Cramer JP, Field VK, Grobusch MP, Caumes $\mathrm{E}$, et al. Travel-related infection in European travelers, EuroTravNet 2011. J Travel Med. 2014;21(4):248-54. https:// doi.org/10.1111/jtm.12120 PMID: 24750378

24. Bacaner N, Stauffer B, Boulware DR, Walker PF, Keystone JS. Travel medicine considerations for North American immigrants visiting friends and relatives. JAMA. 2004;291(23):2856-64. https://doi.org/10.1001/jama.291.23.2856 PMID: 15199037

25. Barnett ED, MacPherson DW, Stauffer WM, Loutan L, Hatz CF, Matteelli A, et al. The visiting friends or relatives traveler in the 21st century: time for a new definition. J Travel Med. 2010;17(3):163-70. https://doi.org/10.1111/j.17088305.2010.00411.x PMID: 20536884

26. Diamond C, Thiede H, Perdue T, Secura GM, Valleroy L, Mackellar D, et al. Viral hepatitis among young men who have sex with men: prevalence of infection, risk behaviors, and vaccination. Sex Transm Dis. 2003;30(5):425-32. https://doi. org/10.1097/00007435-200305000-00009 PMID: 12916134

27. Wasley A, Samandari T, Bell BP. Incidence of hepatitis A in the United States in the era of vaccination. JAMA. 2005;294(2):194201. https://doi.org/10.1001/jama.294.2.194 PMID: 16014593

28. Mellou K, Chrisostomou A, Sideroglou T, Georgakopoulou T, Kyritsi M, Hadjichristodoulou C, et al. Hepatitis A among refugees, asylum seekers and migrants living in hosting facilities, Greece, April to December 2016. Euro Surveill. 2017;22(4):30448. https://doi.org/10.2807/1560-7917. ES.2017.22.4.30448 PMID: 28181904

29. Michaelis K, Wenzel JJ, Stark K, Faber M. Hepatitis A virus infections and outbreaks in asylum seekers arriving to Germany, September 2015 to March 2016. Emerg Microbes Infect. 2017;6(4):e26. https://doi.org/10.1038/emi.2017.11 PMID: 28442750

30. Tjon G, Xiridou M, Coutinho R, Bruisten S. Different transmission patterns of hepatitis $A$ virus for two main risk groups as evidenced by molecular cluster analysis. J Med Virol. 2007;79(5):488-94. https://doi.org/10.1002/jmv.20821 PMID: 17385681

31. Suijkerbuijk AW, Lindeboom R, van Steenbergen JE, Sonder G), Doorduyn Y. Effect of hepatitis A vaccination programs for migrant children on the incidence of hepatitis $A$ in The Netherlands. Eur J Public Health. 2009;19(3):240-4. https:// doi.org/10.1093/eurpub/ckn145 PMID: 19174503

32. Freedman DO, Chen LH, Kozarsky PE. Medical considerations before international travel. N Engl J Med. 2016;375(3):247-60. https://doi.org/10.1056/NEJMra1508815 PMID: 27468061

33. European Centre for Disease Prevention and Control (ECDC). Hepatitis A outbreak in the EU/EEA mostly affecting men who have sex with men. Third update, 28 June 2017. Rapid risk assessment. Stockholm: ECDC; 2017. Available from: https:// ecdc.europa.eu/en/publications-data/rapid-risk-assessmenthepatitis-outbreak-eueea-mostly-affecting-men-who-have-sex

34. Crowcroft NS. What causes hepatitis A in travellers to endemic countries? Travel is necessary but not sufficient--a risk factor, not a cause. Epidemiol Infect. 2012;140(10):1821-2. https:// doi.org/10.1017/S0950268812000064 PMID: 22300866

\section{License and copyright}

This is an open-access article distributed under the terms of the Creative Commons Attribution (CC BY 4.0) Licence. You may share and adapt the material, but must give appropriate credit to the source, provide a link to the licence, and indicate if changes were made.

This article is copyright of the authors, 2018. 